\title{
Colonization and Spore Richness of Arbuscular Mycorrhizal Fungi in Araucaria Nursery Seedlings in Curitiba, Brazil
}

\author{
Carlos Vilcatoma-Medina $\mathbb{D}^{1},{ }^{1}$ Glaciela Kaschuk $\mathbb{D}^{\mathbb{D}},{ }^{2}$ and Flávio Zanette ${ }^{1}$ \\ ${ }^{1}$ Programa de Pós-Graduação em Agronomia-Produção Vegetal, Departamento de Fitotecnia, \\ Federal University of Paraná, Curitiba, PR, Brazil \\ ${ }^{2}$ Programa de Pós-Graduação em Ciência do Solo, Departamento de Solos e Engenharia Agrícola, \\ Federal University of Paraná, Curitiba, PR, Brazil \\ Correspondence should be addressed to Carlos Vilcatoma-Medina; carlos.vilcatoma@ufpr.br
}

Received 19 October 2017; Revised 19 January 2018; Accepted 5 February 2018; Published 1 April 2018

Academic Editor: Mathias N. Andersen

Copyright (C) 2018 Carlos Vilcatoma-Medina et al. This is an open access article distributed under the Creative Commons Attribution License, which permits unrestricted use, distribution, and reproduction in any medium, provided the original work is properly cited.

\begin{abstract}
Araucaria or Paraná pine [Araucaria angustifolia (Bertol.) Kuntze, 1898] is an endangered timber tree species of Atlantic Forest that naturally forms symbiosis with arbuscular mycorrhizal fungi (AMF). The objective of this experiment was to evaluate AMF colonization and spore AMF richness in araucaria seedlings produced in nursery at the metropolitan region of Curitiba, Brazil, with the interest of identifying a taxonomical AMF group. For that, soil and fine roots of 6-month-, 1-year-, 2-year-, 3-year-, and 5 -year-old araucaria seedlings were sampled and evaluated. Evaluations indicated that araucaria seedlings were well colonized by AMF (with rates varying from almost 50 to over $85 \%$ ) and produced an abundant number of mycorrhizal spores (from 344 to 676 spores per seedling). Samples contained spores of the species Acaulospora scrobiculata, Dentiscutata heterogama, and Glomus spinuliferum and unidentified species of genera Gigaspora and Glomus. The Glomus genus was the most abundant kind of AMF spores found under nursery conditions. Therefore, the experiment evidenced that Glomus is a promising genus candidate for being used as AMF inoculant in production of araucaria seedlings.
\end{abstract}

\section{Introduction}

Araucaria or Paraná pine [Araucaria angustifolia (Bertol.) Kuntze, 1898] is an endangered tree species of the Mixed Ombrophilous Forest, commonly known as "Mata das Araucárias," located in southern and the southern east of Brazil and in portions of Argentina and Paraguay [1,2]. The araucaria is a dioecious plant, and its propagation by seeds (pinhões) is conditioned to the existence of intraspecific genetic richness in natural habitat. The problem is that $97 \%$ of the Mata das Araucarias ecosystem has disappeared [3] and reminiscent araucaria trees are isolated from each other and may not form viable seeds. In addition, seeds are rich in carbohydrates and proteins may be consumed by wild animals and rapidly lose vigor when left on dry soil [4]. Reforestation by transplanting seed-formed seedlings is suitable strategy, but it takes too long before nursery seedlings reach adequate height for transplantation. Yet, adding fertilizer to the substrate to increase growth rates may result in lower root, shoot ratio, and consequently decrease the rates of survival in the field after transplantation.

Araucaria naturally establishes symbiosis with arbuscular mycorrhizal fungi (AMF) [4], in which the plant supplies photosynthates in exchange for competitive advantages of growth and survival [5-8]. Pioneer studies already reported AMF in fine araucaria roots [9]; however, it was only recently that the AMF has been considered as a strategy to increase araucaria growth under nursery conditions $[10,11]$. In fact, the studies performed so far show two important facts: first, that araucaria is colonized by a large and diverse number of AMF species [10,12]; and second that the araucaria positively respond to inoculation of some AMF species, both in high and low $\mathrm{P}$ supply [13]. However, we do not know precisely the most efficient and competitive AMF species under nursery seedling production [14]. 
TABLE 1: Chemical attributes of soils used in the nursery experiment with araucaria in Curitiba, Brazil.

\begin{tabular}{|c|c|c|c|c|c|}
\hline \multirow{2}{*}{ Soil attribute ${ }^{*}$} & \multicolumn{5}{|c|}{ Seedling age } \\
\hline & 6 months & 1 year & 2 years & 3 years & 5-years \\
\hline $\mathrm{pH} \mathrm{CaCl}{ }_{2}$ & $5.5 \pm 0.240$ & $4.9 \pm 0.081$ & $5.5 \pm 0.122$ & $5.2 \pm 0.173$ & $4.3 \pm 0.394$ \\
\hline $\mathrm{Al}^{3+}\left(\mathrm{cmol} / \mathrm{dm}^{3}\right)$ & $0.0 \pm 0.0$ & $0.9 \pm 0.176$ & $0.0 \pm 0.0$ & $0.0 \pm 0.042$ & $2.7 \pm 1.494$ \\
\hline $\mathrm{H}+\mathrm{Al}^{3+}\left(\mathrm{cmol} / \mathrm{dm}^{3}\right)$ & $5.1 \pm 0.678$ & $13.2 \pm 1.327$ & $7.4 \pm 0.903$ & $7.2 \pm 0.537$ & $13.9 \pm 2.591$ \\
\hline $\mathrm{Ca}^{2+}\left(\mathrm{cmol} / \mathrm{dm}^{3}\right)$ & $4.3 \pm 0.221$ & $6.1 \pm 0.522$ & $9.4 \pm 0.685$ & $7.1 \pm 1.784$ & $3.0 \pm 1.338$ \\
\hline $\mathrm{Mg}^{2+}\left(\mathrm{cmol} / \mathrm{dm}^{3}\right)$ & $1.8 \pm 0.078$ & $3.7 \pm 0.355$ & $4.3 \pm 0.269$ & $2.9 \pm 0.930$ & $1.6 \pm 1.338$ \\
\hline $\mathrm{K}^{+}\left(\mathrm{cmol} / \mathrm{dm}^{3}\right)$ & $1.1 \pm 0.260$ & $0.3 \pm 0.151$ & $1.0 \pm 0.286$ & $0.7 \pm 0.443$ & $0.2 \pm 0.128$ \\
\hline $\mathrm{P}\left(\mathrm{mg} / \mathrm{dm}^{3}\right)$ & $16.7 \pm 5.390$ & $78.2 \pm 16.967$ & $144.5 \pm 16.408$ & $87.5 \pm 30.295$ & $79.1 \pm 42.421$ \\
\hline $\mathrm{C}\left(\mathrm{g} / \mathrm{dm}^{3}\right)$ & $12.7 \pm 3.457$ & $85.3 \pm 27.451$ & $64.3 \pm 11.419$ & $46.7 \pm 16.486$ & $61.4 \pm 55.447$ \\
\hline
\end{tabular}

${ }^{*} \mathrm{pH}$ measured in $\mathrm{CaCl}_{2} 0.01 \mathrm{~mol} \mathrm{~L}^{-1} ; \mathrm{Ca}^{2+}, \mathrm{Mg}^{2+}$, and $\mathrm{Al}^{3+}$ extracted with $\mathrm{KCl} 1 \mathrm{~mol} \mathrm{~L}^{-1} ; \mathrm{H}^{+}+\mathrm{Al}^{3+}$ extracted with calcium acetate $0.5 \mathrm{~mol} \mathrm{~L}{ }^{-1} ; \mathrm{K}^{+}$and $\mathrm{P}$ extracted with the Mehlich-1 extractor; $\mathrm{C}$ determined with $\mathrm{K}_{2} \mathrm{Cr}_{2} \mathrm{O}_{7}$.

Therefore, the objective of this experiment was to evaluate AMF colonization and spore AMF richness in nursery soil samples at the metropolitan region of Curitiba, Brazil, with the interest of identifying the most abundant taxonomical AMF groups that grow under those conditions.

\section{Material and Methods}

Araucaria seedlings were produced from seeds in the nursery of the Universidade Federal do Paraná, Curitiba $\left(25^{\circ} 25^{\prime} 47^{\prime \prime} \mathrm{S}\right.$ and $\left.49^{\circ} 16^{\prime} 19^{\prime \prime} \mathrm{W}, 950 \mathrm{~m}\right)$, Brazil, under entirely random design, five replicates, and five treatments. The substrate used was a mixture of soil and organic residues (crop residues, organic compounds, and others) collected in the metropolitan area of the city. The experimental design was completely randomized, with five replications in each treatment. The seedlings were at the moment of harvesting, according to the respective treatments: 6-month, 1-year, 2 -year, and 5year old. Seedlings grew outdoors, under full light natural conditions, and were well watered during the whole period of experiment. The climate in the region is classified as Köppen $\mathrm{Cfb}$ [15] and the eventual climate events such as frost and storms did not damage any stage of plant growth.

Soil samples were submitted to chemical analyses, and the $\mathrm{pH}$ was measured in $\mathrm{CaCl}_{2} 0.01 \mathrm{~mol} \mathrm{~L}{ }^{-1} ; \mathrm{Ca}^{2+}, \mathrm{Mg}^{2+}$, and $\mathrm{Al}^{3+}$ were extracted with $\mathrm{KCl} 1 \mathrm{M} ; \mathrm{H}^{+}+\mathrm{Al}^{3+}$, with $\mathrm{Ca}\left(\mathrm{C}_{2} \mathrm{H}_{3} \mathrm{O}_{2}\right)_{2} 0.5 \mathrm{M} ; \mathrm{K}^{+}$and $\mathrm{P}$, with the Mehlich-1 extractor; carbon $(\mathrm{C})$, with the $\mathrm{K}_{2} \mathrm{Cr}_{2} \mathrm{O}_{7}$ (Table 1).

Mycorrhizal spores were extracted with minor modifications with the procedures of $[16,17]$ as follows: $100 \mathrm{~g}$ of soil sample was suspended in $100 \mathrm{ml}$ and left resting for $60 \mathrm{~min}$; soil suspensions were liquefied for $10 \mathrm{~s}$ and sequentially sieved through 500 and $53 \mu \mathrm{m}$ mesh sieves; spores were recovered in tubes with $70 \%$ sucrose solution and centrifuged for four min twice and then sieved for 250 and $50 \mu \mathrm{m}$ mesh sieves. Spores with similar morphology were assembled; then, they were spread on microscope slide and treated with polyvinyl alcohol-lactic acid-glycerol [18] and the Melzer reagent [19]. Spores were individually identified under microscope (Primo Star/Zeiss) according to the morphological characteristics using the criteria of taxonomical classification proposed by Invam [20].

Root fragments were preserved in lactoglycerol (lactic acid, glycerol, and water in the proportion $1: 2: 1$ ) before

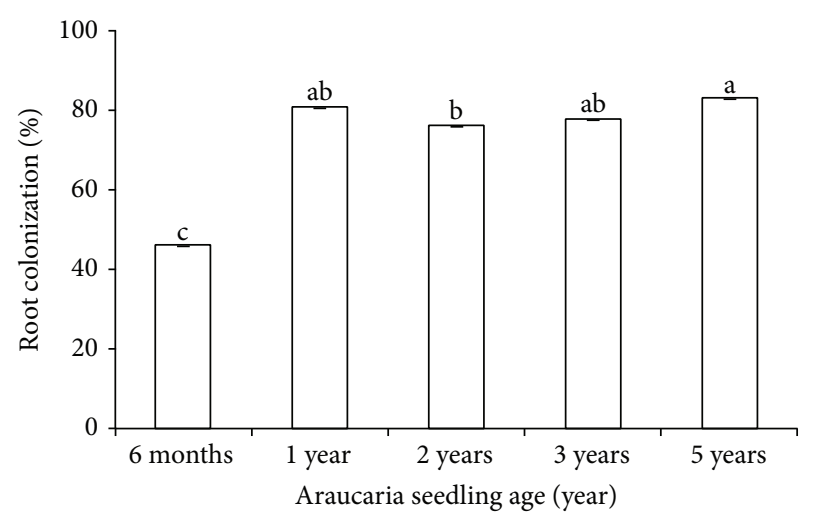

FIgURE 1: Root arbuscular mycorrhizal fungi (AMF) colonization araucaria seedlings with ages between 6 months and 5 years grown in a nursery in field in Curitiba, Brazil. Means followed by the same letter are not significantly different according to Tukey's test ( $p \leq$ 0.05 ). The error bars represent the standard error of the mean. $n=5$.

measurements. The rates of mycorrhizal colonization were estimated by observing cleared and dyed root fragments under microscope (Stemi 305/Zeiss), considering a grid of $1 \mathrm{~cm} \times 1 \mathrm{~cm} \mathrm{[21],} \mathrm{with} \mathrm{minor} \mathrm{modifications,} \mathrm{as} \mathrm{follows:} \mathrm{fine}$ roots were soaked in $\mathrm{KOH} 10 \%$ at room temperature during 24 hours and then, in water bath at $80^{\circ} \mathrm{C}$ for an hour; roots were sequentially washed with $\mathrm{H}_{2} \mathrm{O}_{2} 100 \%$ and water twice and dyed with blue-pen ink in water bath at $80^{\circ} \mathrm{C}$ for five minutes.

Variance analyses and mean comparisons considered the statistical design of entirely random design, five replicates, and five treatments. Redundancy analyses were performed with Canoco for Windows 4.5 package 43, considering the abundance of spore taxonomic group and chemical attributes as the explanatory variables for the differences between the treatments.

\section{Results}

Araucaria seedlings with ages between 6 months and 5 years produced under nursery conditions in Curitiba were well colonized by AMF (rates varying from almost 50 to over $85 \%$; Figure 1) and contained an abundant number of mycorrhizal 
TABLE 2: Mean number of mycorrhizal spores of araucaria seedlings with ages between 6 months and 5 years grown in a nursery field in Curitiba, Brazil.

\begin{tabular}{|c|c|c|c|c|c|}
\hline \multirow{2}{*}{ Mycorrhizal fungal species } & \multicolumn{5}{|c|}{ Seedling age (year) } \\
\hline & 6 months & 1 year & 2 years & 3 years & 5 years \\
\hline Acaulospora scrobiculata & $13^{\mathrm{b}}$ & $46^{\mathrm{ab}}$ & $44^{\mathrm{ab}}$ & $70^{\mathrm{a}}$ & $33^{\mathrm{b}}$ \\
\hline Dentiscutata heterogama & $11^{\mathrm{a}}$ & $16^{\mathrm{a}}$ & $15^{\mathrm{a}}$ & $17^{\mathrm{a}}$ & $15^{\mathrm{a}}$ \\
\hline Gigaspora sp. & $9^{\mathrm{b}}$ & $29^{\mathrm{a}}$ & $8^{\mathrm{b}}$ & $12^{\mathrm{b}}$ & $11^{\mathrm{b}}$ \\
\hline Glomus spinuliferum & $31^{\mathrm{b}}$ & $114^{\mathrm{a}}$ & $53^{\mathrm{b}}$ & $129^{\mathrm{a}}$ & $118^{\mathrm{a}}$ \\
\hline Glomus sp. 1 & $40^{\mathrm{ab}}$ & $28^{\mathrm{b}}$ & $40^{\mathrm{ab}}$ & $62^{\mathrm{a}}$ & $34^{\mathrm{ab}}$ \\
\hline Glomus sp. 2 & $91^{\mathrm{a}}$ & $142^{\mathrm{a}}$ & $55^{\mathrm{a}}$ & $161^{\mathrm{a}}$ & $141^{\mathrm{a}}$ \\
\hline Glomus sp. 3 & $101^{\mathrm{c}}$ & $187^{\mathrm{a}}$ & $82^{c}$ & $111^{b c}$ & $176^{\mathrm{ab}}$ \\
\hline Glomus sp. 4 & $48^{\mathrm{b}}$ & $153^{\mathrm{a}}$ & $57^{\mathrm{b}}$ & $73^{\mathrm{b}}$ & $148^{\mathrm{a}}$ \\
\hline Total of species & $344^{\mathrm{b}}$ & $715^{\mathrm{a}}$ & $355^{\mathrm{b}}$ & $635^{\mathrm{a}}$ & $676^{\mathrm{a}}$ \\
\hline
\end{tabular}

Means followed by the same letter in the lines do not differ by the Tukey test at $p<0,05$.

spores (varying from 344 to 676; Table 2). Samples contained spores of the species Acaulospora scrobiculata, Dentiscutata heterogama, and Glomus spinuliferum and of four unidentified species of the genera Gigaspora (one species) and Glomus (four different species).

Mycorrhizal fungi colonization increases from 40 to around $80 \%$ in seedlings of 6 months -1 year old. From 1 year onwards, regardless of chemical differences in the soil used, rates of AMF colonization remained at levels of $80 \%$ over the years. At first sight, there was a trend in which older seedlings (3- and 5-year old) contained more spores than younger (e.g., 6 months and 2 years old) seedlings, but because 2 -year old araucaria seedlings contained the largest number of spores, age was not the main factor affecting the number of spores in this experiment.

The dominant AMF species in the 6-month, 1-year, 2-year, and 5-year old seedlings was Glomus sp. 3 and in the 3 years old seedlings, it was Glomus sp. 2 (Table 2). The least abundant spores belonged to the family Gigasporaceae (Dentiscutata heterogama and Gigaspora sp.), and their numbers did not differ between treatments.

Redundancy analyses showed that AMF spore richness in 6-month old seedlings was not affected by soil chemical attributes, but it was so in older seedlings (Figure 2). Attributes related to potential soil acidity $\left(\mathrm{Al}^{+}\right.$and $\left.\mathrm{H}+\mathrm{Al}^{+}\right)$ grouped AMF species Glomus sp. 3, Glomus sp. 4, and Gigaspora sp. Attributes related to good soil fertility (Ca, $\mathrm{Mg}$, and P) grouped mycorrhizal fungi species Glomus sp. 1. Dentiscutata heterogama, Acaulospora scrobiculata, and Glomus sp. 1 (Figure 2).

\section{Discussion}

Perennial plants with slow growth like araucaria are not commonly taken into long-term experiments involving AMF because of the obvious difficulty of waiting for a long time for the first results (e.g., compared to annual crops) and also because araucaria is not the first choice of reforestation by companies. Therefore, although AMF colonization has been studied long ago [9], our experiment demonstrated that AMF colonization occurs under nursery conditions to seedlings from very young age up to 5-year old seedlings, without systematic inoculation and regardless of chemical soil attributes (Figure 1; Table 1). This implies that, in addition to field natural conditions [10,22], araucaria seedlings are also benefited from AMF colonization under nursery conditions.

A great limitation in the application of AMF symbiosis is the fact that we do not have established recommendations of which AMF species are better adapted to nursery and field conditions. Previous studies indicated that araucaria is capable of supporting AMF symbiosis with a greater number of different fungal species [11, 22-25] than that we found in this experiment. To date, araucaria AMF spore richness varied from 8 [23] to 13 [11] in forests of the State of Rio Grande do Sul and from 26 [24] to 58 [25] in forests of Sao Paulo. The variation in spore AMF richness has been frequently attributed to heterogeneity in soil habitat and to the variable capacity of AMF species to adapt to climate and soil in different regions $[10,13]$. Therefore, although the AMF richness is great under field conditions, only few species are probably well adapted to nursery conditions.

The genus Glomus represented $86 \%$ of the spores analyzed in our experiment (Table 2). Previously, it was observed that this genus represented between 40 and $60 \%$ of AMF spores in forests in the State of Sao Paulo [10, 22]. In fact, soil acidity associated with exchangeable soil $\mathrm{Al}\left(\mathrm{Al}^{+}\right)$may affect spore germination, growth of germinative tube, hyphae, and root [26]. Furthermore, concentrations higher than $100 \mu \mathrm{m} \mathrm{Al}$ affect sporulation of certain species [27]. In this experiment, potential acidity determined by high concentrations of $\mathrm{Al}^{+}$ and $\mathrm{H}+\mathrm{Al}^{+}$was associated with Glomus sp. 3 and Glomus sp. 4 (Figure 2). The Glomus genus is the most commonly found and probably the most adapted AMF to Brazilian acidy soils $[28,29]$. This dominancy indicates that Glomus is highly competitive among native spores and it has a high reproductive capacity [10].

The Acaulospora genus was the second most abundant AMF spore in the experiment (Table 2), corroborating with the fact that the Acaulospora AMF has been found in moderate acidy soils (pH lower than 6.2) [30] and very acidy forest soils [24]. The least abundant genus in this experiment belonged to the genus Gigaspora (Table 2). Gigaspora has been 


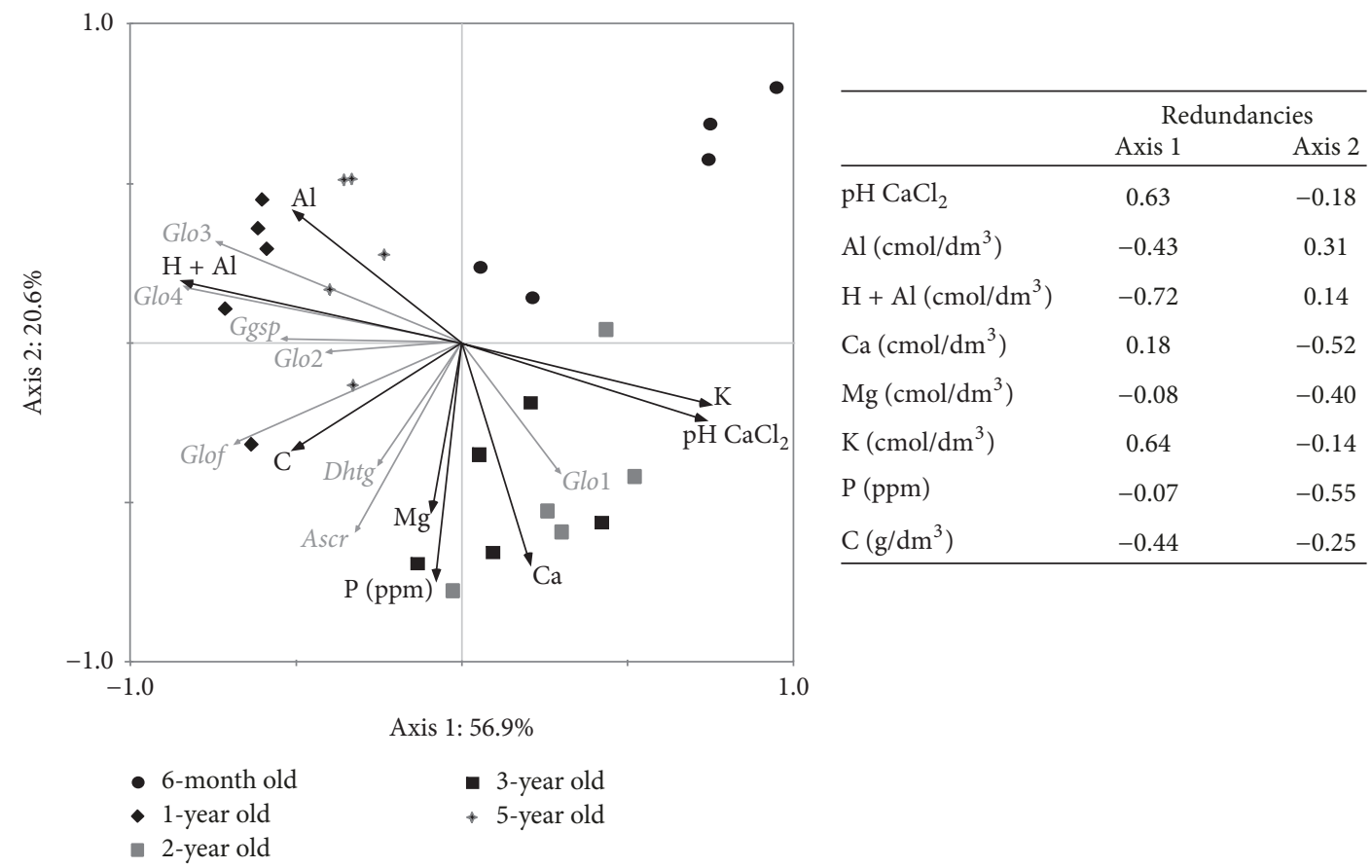

FIGURE 2: Redundancy analyses with several species of arbuscular mycorrhizal fungi in relation to chemical soil attributes in soil used to produce araucaria seedlings in a nursery of Curitiba, Brazil. Note: Ascr: Acaulospora scrobiculata; Dhtg: Dentiscutata heterogama; Ggsp: Gigaspora sp.; Glof: Glomus spinuliferum; Glo1: Glomus sp. 1; Glo2: Glomus sp. 2; Glo3: Glomus sp. 3; Glo4: Glomus sp. 4.

associated with moderate acidy soils and high levels of phosphate availability $[13,14]$. In our experiment, however, Gigaspora was not related to phosphate but it was slightly associated with potential soil acidity $\left(\mathrm{Al}^{+}\right.$and $\mathrm{H}+\mathrm{Al}^{+}$; Figure 2).

The traditional paradigm describes regulation of AMF symbioses in relation to phosphate availability, in which plants suppress AMF colonization once phosphate is available in enough quantities for being taken from the soil solution. However, this paradigm neglects some aspects of AMF physiology. Reference [31] gave evidence that after the AMF has colonized root wheat (Triticum aestivum L.) plants, it does not let it down, even if phosphate is available in enough quantities. It does not imply necessarily that AMF is always efficient regardless of $\mathrm{P}$ availability. In fact, $\mathrm{P}$ availability determines different AMF compositions and, therefore, different AMF efficiencies [32]. Earlier studies than that of [31] demonstrated that plant growth responses to AMF inoculation under low and high phosphate availability depend very much on the dominant AMF [33]. In that aspect, the genus Glomus had a much greater phosphate uptake efficiency than Gigaspora [33]. Interestingly, greater efficiency of Glomus over Gigaspora (increased mycorrhizal dependence of plants) was also measured on araucaria seedlings produced with $150 \mathrm{mg} \mathrm{dm}^{-3}$ soil of phosphate fertilizer [14]. Previous studies indicated that mycorrhizal colonization occurs when plants are grown in soils that contain less than $40 \mathrm{mg} \mathrm{dm}^{-3}$ [32]. In the present study, the substrate contained $62 \mathrm{mg}$ of $\mathrm{P} \mathrm{dm}^{-3}$, and even so Araucaria seedlings were well colonized by mycorrhizae, especially with the genus Glomus. This is an observation that should derive more research in our group.
Considering the greater abundance of Glomus in relation to other genera, our experiment suggested that other studies should search within Glomus diversity to identify AMF inoculants that promote growth of araucaria seedlings. The next step is selecting strains, checking for consistent plant growth responses, and evaluating the viability in inoculant production at commercial scale. As Glomus was not related to P soil concentrations in soil samples (Figure 2), it is important that selection occurs under reasonable soil chemical conditions. As a matter of fact, it has been shown that AMF symbioses may be favored by better plant growth [34] and high potential acidity (high $\mathrm{Al}^{+}$) inhibits root growth, damages cellular structure, and hampers water and nutrient $[35,36]$.

\section{Conclusions}

Araucaria seedlings are intensively colonized by AMF at least until the age of 5 years old, even when they are not systematically inoculated with specific AMF strains.

Glomus genus is the most abundant kind of AMF spores found under nursery conditions, and therefore other studies should search within Glomus diversity to identify AMF inoculants that promote growth of araucaria seedlings.

\section{Conflicts of Interest}

The authors declare that they have no conflicts of interest.

\section{Acknowledgments}

Authors thank Dr. Celso Auer, Dr. Sidney Stürmer, and Dr. Raul M. Cesar, respectively, for the suggestions on 
the experimental setup, training on spore identification, and statistical analyses. Carlos Vilcatoma-Medina received a CAPES (Coordenação de Aperfeiçoamento de Pessoal de Nível Superior) scholarship to pursue his Ph.D. studies.

\section{References}

[1] P. Thomas, "Araucaria angustifolia," The IUCN Red List of Threatened Species, Article ID e.T32975A2829141, 2013.

[2] G. F. Paludo, M. B. Lauterjung, M. S. dos Reis, and A. Mantovani, "Inferring population trends of Araucaria angustifolia (Araucariaceae) using a transition matrix model in an oldgrowth forest," Southern Forests, vol. 78, no. 2, pp. 137-143, 2016.

[3] V. M. Stefenon, O. Gailing, and R. Finkeldey, "Genetic structure of Araucaria angustifolia (Araucariaceae) populations in Brazil: implications for the in situ conservation of genetic resources," The Journal of Plant Biology, vol. 9, no. 4, pp. 516-525, 2007.

[4] R. B. Zandavalli, L. R. Dillenburg, and P. V. D. De Souza, "Growth responses of Araucaria angustifolia (Araucariaceae) to inoculation with the mycorrhizal fungus Glomus clarum," Applied Soil Ecology, vol. 25, no. 3, pp. 245-255, 2004.

[5] S. Gianinazzi, A. Gollotte, M.-N. Binet, D. van Tuinen, D. Redecker, and D. Wipf, "Agroecology: the key role of arbuscular mycorrhizas in ecosystem services," Mycorrhiza, vol. 20, no. 8, pp. 519-530, 2010.

[6] S. E. Smith and F. A. Smith, "Roles of arbuscular mycorrhizas in plant nutrition and growth: New paradigms from cellular to ecosystem scales," Annual Review of Plant Biology, vol. 62, pp. 227-250, 2011.

[7] S. E. Smith and F. A. Smith, "Fresh perspectives on the roles of arbuscular mycorrhizal fungi in plant nutrition and growth," Mycologia, vol. 104, no. 1, pp. 1-13, 2012.

[8] S. C. Jung, A. Martinez-Medina, J. A. Lopez-Raez, and M. J. Pozo, "Mycorrhiza-induced resistance and priming of plant defenses," Journal of Chemical Ecology, vol. 38, no. 6, pp. 651664, 2012

[9] F. R. Milanez and H. Monteiro Neto, "Nota prévia sobre micorriza no pinho do Paraná," Arquivos do Serviço Florestal, vol. 4, pp. 87-93, 1950.

[10] M. Moreira-Souza, S. F. B. Trufem, S. M. Gomes-Da-Costa, and E. J. B. N. Cardoso, "Arbuscular mycorrhizal fungi associated with Araucaria angustifolia (Bert.) O. Ktze," Mycorrhiza, vol. 13, no. 4, pp. 211-215, 2003.

[11] R. B. Zandavalli, S. L. Stürmer, and L. R. Dillenburg, "Species richness of arbuscular mycorrhizal fungi in forests with Araucaria in Southern Brazil," Hoehnea, vol. 35, no. 1, pp. 63-68, 2008.

[12] M. Moreira, M. I. Zucchi, J. E. Gomes, S. M. Tsai, A. AlvesPereira, and E. J. B. N. Cardoso, "Araucaria angustifolia aboveground roots presented high arbuscular mycorrhizal fungal colonization and diversity in the Brazilian Atlantic Forest," Pedosphere, vol. 26, no. 4, pp. 561-566, 2016.

[13] M. Moreira, D. Baretta, and E. J. Cardoso, "Doses de fósforo determinam a prevalência de fungos micorrízicos arbusculares em Araucaria angustifolia," Ciência Florestal, vol. 22, no. 4, pp. 813-820, 2012.

[14] M. Moreira-Souza and E. J. Cardoso, "Dependência micorrízica de Araucaria angustifolia (Bert.) O. Ktze. sob doses de fósforo," Revista Brasileira de Ciência do Solo, vol. 26, no. 4, pp. 905-912, 2002.
[15] C. A. Alvares, J. L. Stape, P. C. Sentelhas, J. L. De Moraes Gonçalves, and G. Sparovek, "Köppen's climate classification map for Brazil," Meteorologische Zeitschrift, vol. 22, no. 6, pp. 711-728, 2013.

[16] J. Gerdemann and T. H. Nicolson, "Spores of mycorrhizal endogone species extracted from soil by wet sieving and decanting," Transactions of the British Mycological Society, vol. 46, pp. 235-244, 1963.

[17] W. R. Jenkins, "A rapid centrifugation technique for separating nematodes from soil," Plant Disease Report, vol. 48, article 692, 1964.

[18] J. B. Morton, S. P. Bentivenga, and W. W. Wheeler, "Germ plasm in the International Collection of Arbuscular and VesicularArbuscular Mycorrhizal Fungi (INVAM) and procedures for culture development, documentation and storage," Mycotaxon, vol. 48, pp. 491-528, 1993.

[19] R. E. Koske and B. Tessier, "A convenient, permanent slide mounting medium," Mycological Society of America Newslette, vol. 34, article 59, 1983.

[20] INVAM, "International culture collection of (vesicular) arbuscular mycorrhizal fungi," https://invam.wvu.edu/.

[21] M. Giovannetti and B. Mosse, "An evaluation of techniques for measuring vesicular arbuscular mycorrhizal infection in roots," New Phytologist, vol. 84, no. 3, pp. 489-500, 1980.

[22] M. Moreira, M. A. Nogueira, S. M. Tsai, S. M. Gomes-DaCosta, and E. J. B. N. Cardoso, "Sporulation and diversity of arbuscular mycorrhizal fungi in Brazil Pine in the field and in the greenhouse," Mycorrhiza, vol. 17, no. 6, pp. 519-526, 2007.

[23] M. Breuninger, W. Einig, E. Magel, E. Cardoso, and R. Hampp, "Mycorrhiza of Brazil pine (Araucaria angustifolia [Bert. O. Ktze.])," The Journal of Plant Biology, vol. 2, no. 1, pp. 4-10, 2000.

[24] M. Moreira, D. Baretta, S. M. Tsai, and E. J. B. N. Cardoso, "Arbuscular mycorrhizal fungal communities in native and in replanted Araucaria forest," Scientia Agricola, vol. 66, no. 5, pp. 677-684, 2009.

[25] J. A. Bonfim, R. L. F. Vasconcellos, T. Gumiere, D. de Lourdes Colombo Mescolotti, F. Oehl, and E. J. B. Nogueira Cardoso, "Diversity of arbuscular mycorrhizal fungi in a Brazilian Atlantic Forest Toposequence," Microbial Ecology, vol. 71, no. 1, pp. 164-177, 2016.

[26] A. Seguel, J. R. Cumming, K. Klugh-Stewart, P. Cornejo, and F. Borie, "The role of arbuscular mycorrhizas in decreasing aluminium phytotoxicity in acidic soils: a review," Mycorrhiza, vol. 23, no. 3, pp. 167-183, 2013.

[27] K. Klugh-Stewart and J. R. Cumming, "Organic acid exudation by mycorrhizal Andropogon virginicus L. (broomsedge) roots in response to aluminum," Soil Biology \& Biochemistry, vol. 41, no. 2, pp. 367-373, 2009.

[28] N. C. Johnson and D. A. Wedin, "Soil carbon, nutrients, and mycorrhizae during conversion of dry tropical forest to grassland," Ecological Applications, vol. 7, no. 1, pp. 171-182, 1997.

[29] C. M. R. Pereira, D. K. A. D. Silva, A. C. D. A. Ferreira, B. T. Goto, and L. C. Maia, "Diversity of arbuscular mycorrhizal fungi in Atlantic forest areas under different land uses," Agriculture, Ecosystems \& Environment, vol. 185, pp. 245-252, 2014.

[30] S. L. Sturmer and M. M. Bellei, "Composition and seasonal variation of spore populations of arbuscular mycorrhizal fungi in dune soils on the island of Santa Catarina, Brazil," Botany, vol. 72, no. 3, pp. 359-363, 1994.

[31] H. Li, S. E. Smith, R. E. Holloway, Y. Zhu, and F. A. Smith, "Arbuscular mycorrhizal fungi contribute to phosphorus uptake 
by wheat grown in a phosphorus-fixing soil even in the absence of positive growth responses," New Phytologist, vol. 172, no. 3, pp. 536-543, 2006.

[32] C. D. Collins and B. L. Foster, "Community-level consequences of mycorrhizae depend on phosphorus availability," Ecology, vol. 90, no. 9, pp. 2567-2576, 2009.

[33] S. E. Smith, F. A. Smith, and I. Jakobsen, "Mycorrhizal fungi can dominate phosphate supply to plants irrespective of growth responses," Plant Physiology, vol. 133, no. 1, pp. 16-20, 2003.

[34] J. A. Mensah, A. M. Koch, P. M. Antunes, E. T. Kiers, M. Hart, and H. Bücking, "High functional diversity within species of arbuscular mycorrhizal fungi is associated with differences in phosphate and nitrogen uptake and fungal phosphate metabolism," Mycorrhiza, vol. 25, no. 7, pp. 533-546, 2015.

[35] L. V. Kochian, M. A. Piñeros, J. Liu, and J. V. Magalhaes, "Plant adaptation to acid soils: the molecular basis for crop aluminum resistance," Annual Review of Plant Biology, vol. 66, pp. 571-598, 2015.

[36] Z. Rengel, J. Bose, Q. Chen, and B. N. Tripathi, "Magnesium alleviates plant toxicity of aluminium and heavy metals," Crop \& Pasture Science, vol. 66, no. 12, pp. 1298-1307, 2015. 


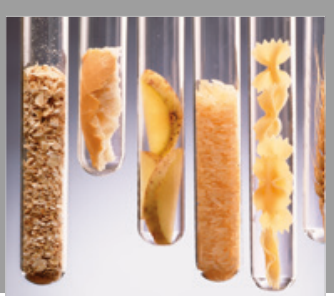

International Journal of Food Science

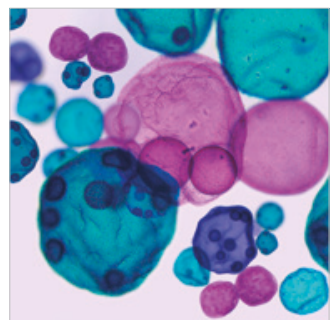

International Journal of Microbiology
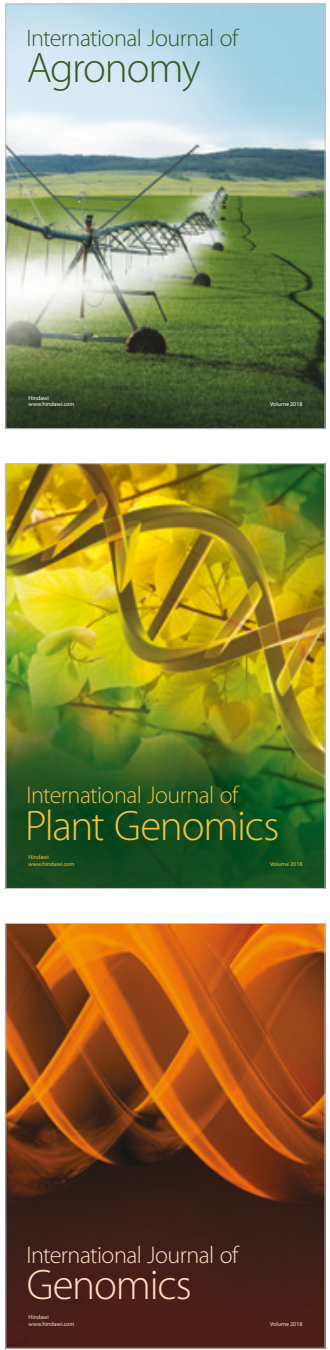

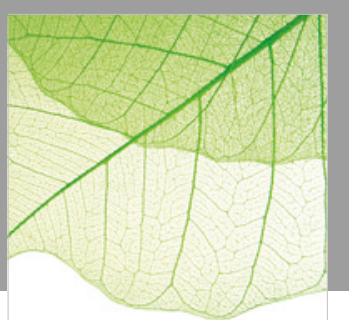

Journal of Botany
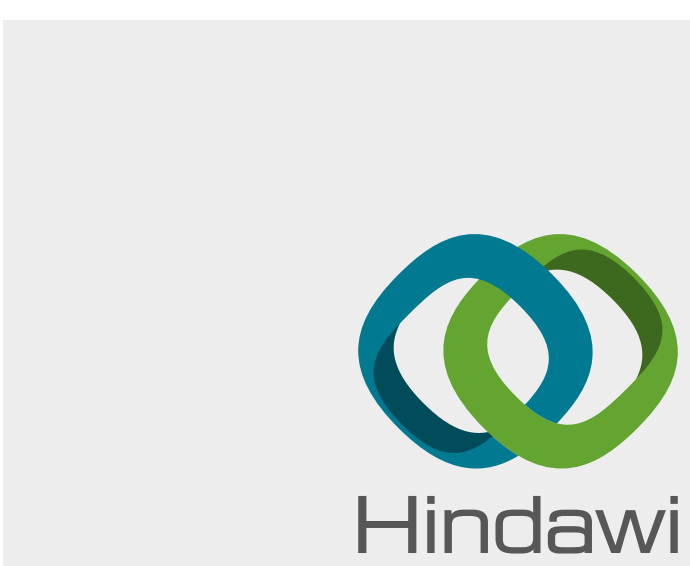

Submit your manuscripts at

www.hindawi.com
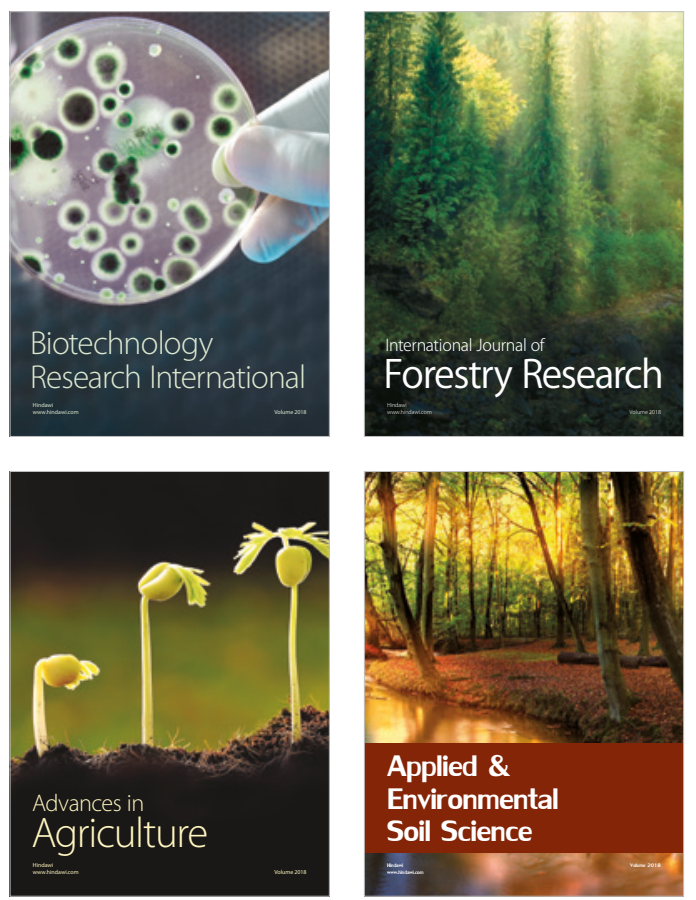

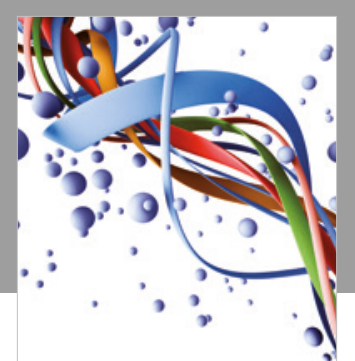

Scientifica

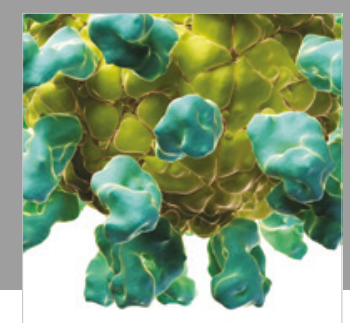

Veterinary Medicine International

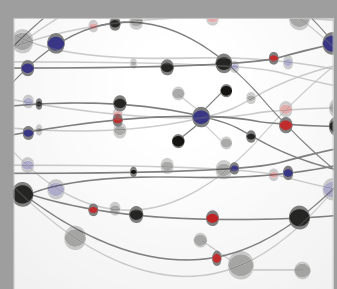

The Scientific World Journal
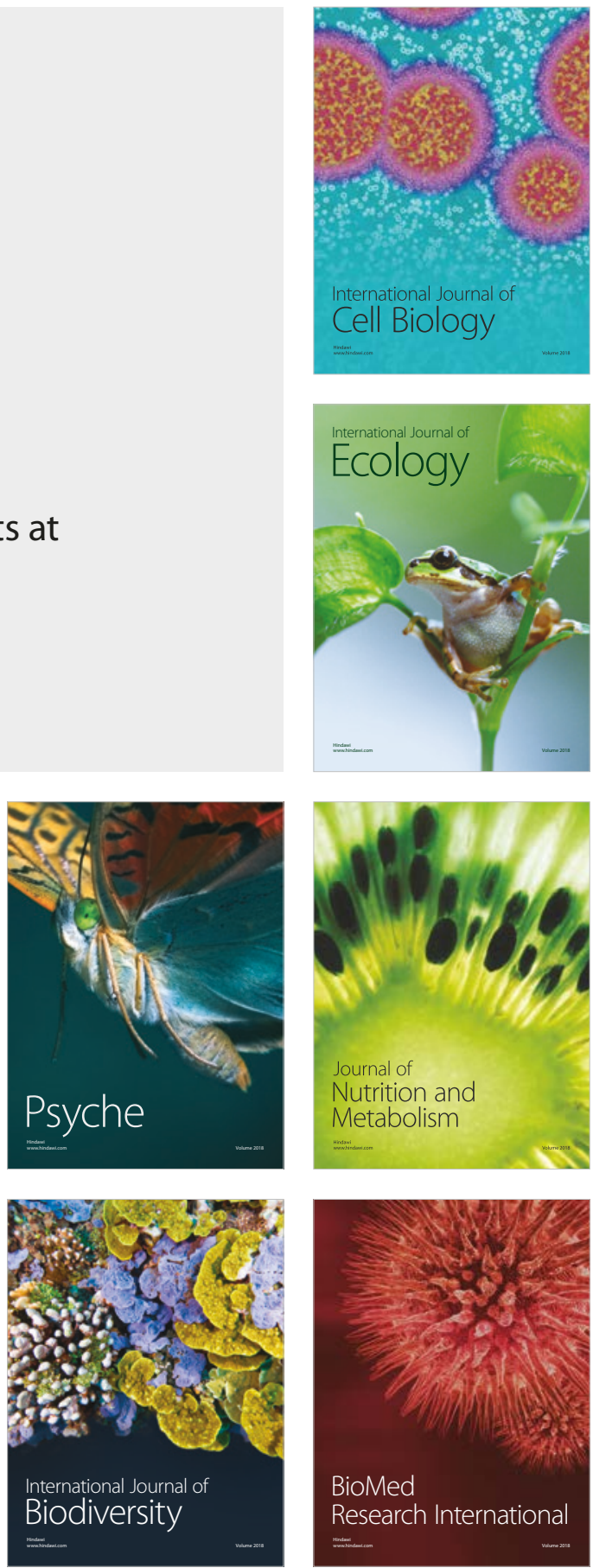